\title{
Considering the Ordo as Pedagogical Context for Religious Education with Christian High School Youth
}

Fred P. Edie, Asst. Prof. for the Practice of Christian Education

Duke Divinity School

September, 2004

\section{Introduction}

Like many of its peer institutions, Duke Divinity School received a generous grant from the Lilly Endowment in the year 2000 for strengthening congregations through theological initiatives with high school youth. Lilly's hope was to provide talented young persons with knowledge and skills to empower them for deeper and more effective life and ministry in the church. For Duke as well as for other schools, these grants also meant the chance to rethink the meaning of the church's ministry with youth and its role in supporting that ministry.

One result of this rethinking, the "Duke Youth Academy for Christian Formation," also provides the context for this essay. ${ }^{1}$ Each summer 50 older high school youth gather on Duke's campus with approximately 35 adults including a dozen or so Divinity School faculty for the purpose of living together in intentional Christian community over two weeks time. The academy is shaped by attention to the $o r d o$, an ecology of interrelated liturgical practices dating to the church of antiquity. The ordo includes the patterning of daily, weekly, and seasonal life (calendar) around occasions for prayer and worship with attention to Christian ritual symbolic practices involving book (scriptures), table (eucharist), and bath (baptism). In an effort to be faithful to this pattern, each day of the academy is centered in word and table worship and book-ended by morning and evening prayer. Faculty teaching plenaries proceed from the ritual/symbolic practices of baptism to spell out theological themes including creation and providence, covenant, Christology, ecclesiology and eschatology. In addition, many days include ordo-inspired practices of servant ministry in the Durham area: hospitality meals shared with diverse local congregations; introduction to the relationship between aesthetics and theology through artistic practice in an "arts village;" and multiple opportunities for reflection in small covenant groups. Among the goals of the academy are forming students more deeply into Christian baptismal identity and, by extension, for more faithful participation in their baptismal vocations in church and world. For the purposes of this essay, the youth academy's practice of the ordo will serve as the arena to explore its adequacy as a form of contextual pedagogy.

Religious educators fashion contextual pedagogies for a variety of reasons. My own list is partial. It includes, first, the conviction that the end of religious education is the embodiment of a religious way of life in community. Since lives do not get lived in general but in particular times, places and in and through specific social locations, pedagogies that seek to shape lives must, out of necessity, attend to such contextual

\footnotetext{
${ }^{1}$ A detailed description of academy life may be found in Edie 2002, 85-107.
} 
realities. Second, religious educators who utilize contextual pedagogies do so out of the conviction that attending to context also provides a means to attend to difference.

Attention to difference, by extension, has come to be understood as a crucial navigational aid for those attempting to specify what constitutes authentic religious activity in the world.

Having construed contextual pedagogies in this way, I seek in this essay to wrestle with the question of whether or not the ecology of interrelated practices that constitute the Duke Youth Academy qualify as such. Certainly our pedagogies, rooted as they are in actual liturgical practices of the church seem contextual enough, but, on the other hand, are they sufficiently contextual to take seriously the concrete realities of Christian North American high school youth? And certainly a community patterned by the ordo and selfconsciously described as "learning to swim in baptismal waters" is different from the youth ministry practices of most students' local parishes, but is this difference capable of shaping them as bearers of prophetic truth? In other words, does the academy create contexts capable of forming but also transforming adolescent lives in relation to church and world and in the best spirit of pedagogies of context? In working through these questions in this essay, I aspire to more clarity in the task of critical reflection on the academy. In the process, however, I hope to push the conversation forward with regard to what constitutes pedagogies of context for religious educators. From my own context as a Christian religious educator, this requires that contextual pedagogies themselves be theologically grounded consistent with Christian theological conviction and that these pedagogies lead toward cultivating distinctly theological knowledge and practice in communities.

\section{Background for Religious Educational Pedagogies of Context}

Any consideration of contextual pedagogies begins well with the work of Paulo Freire and the tradition of religious education informed by his work. As Freire (1994) spells out, education is a political endeavor oriented toward full "humanization" for its subjects, especially for the poor and otherwise oppressed (25). He begins with a critique of what he calls a "banking" model of education whereby those in power maintain structures of dehumanization by withholding from the oppressed the means to discern critically their current oppressive situations. By contrast Freire advocates a process he calls a "problem posing" (60) approach. By equipping persons to name their present situations with critical intentionality, he hopes they also will become empowered to imagine that these situations may be transformed. Freire's pedagogical process unfolds in a dynamic and reciprocal praxis movement of critical reflection toward humanizing action followed by subsequent critical reflection toward action and so on. Consistent with theologies of liberation, Freire also insists that this movement proceeds by attending to difference. Assisting persons on the margins of society in finding their own "voices" is essential for naming both the dynamics of oppression and the practices of liberation.

Freire's seminal contributions to the theory and practice of Christian religious education are notably evident in the work of Michael Warren (1998). Warren contends that youth are largely "silenced" by systems that maintain coercive power over them by exercising 
control over their imaginal horizons (25-42). He argues that they are duped into complicity with these systems (fighting our wars for us, for example), because nowhere are they learning skills for critically assessing the oppressive wider cultural agenda. Warren effectively skewers the church at this point for its domesticated practices of youth ministry, practices he describes as "programs" largely run by adults that effectively contribute to youthful silence. His unmasking of unchallenged youth ministry assumptions reveals models rooted more in consumption, competition and entertainment (think mini-bikes, funny skits and super slides at kids only camps) than Gospel where formation into Christian faith is either absent altogether or so spiritualized that it is incapable of contesting its underlying captivity to principalities and powers. Less evident in Warren's account, however, is the work of theological critique and re-construction. Warren proceeds from a general sense that the Gospel bestows upon persons vocations for peace and justice. This is more assumed than specified, and, for reasons I will articulate below, assuming theological resources to be available and self-evident to youth (in this case in relation to vocation) may be problematic. Thomas Groome (1991) offers a constructive way forward. Between the praxis poles of critical reflection on the present situation and constructive action he inserts "Making Accessible Christian Story and Vision" (215-248). Presumably Groome includes this movement to ensure that the normative content(s) (including theological resources) of Christian faith are made explicitly present to the dialectical task. Of course, a great deal depends upon the manner and substance of this access if Christian religious education is to be theological in character.

Because Freire, Warren, and Groome have deeply influenced my understanding of pedagogies of context, they have also influenced the shape of the youth academy. Academy life is patterned by an ecology of shared practices. Every dimension of that life partakes of the praxis dynamics of preparation, participation (practice) and critical reflection leading toward more faithful practice. The ordo is intended to be the primary means for making accessible the story and vision. We assume that communal experience and practice are the starting points for Christian religious education.

\section{Questions About the Ordo as an Adequate Pedagogical Context for Christian Youth}

Yet I dare not allow commonalities to gloss over differences (especially in an essay on contextual pedagogies). At the outset, for example, it would seem that pedagogies rooted in the ordo and in the theology and practice of Christian baptism are located anywhere but the heart of teenage Christian life. Students do not come to us saying, "Dude, let's work through baptism." Indeed, in a survey students complete prior to attending the youth academy, one that inquires about their Christian practices including their worshiping practices, a portrait of their religious attitudes, practices and contexts emerges. This portrait seems not to share much in common with the ordo. First, students think of religious practices including prayer and scripture reading as personal practices for individuals. Second, approximately half specifically disavow worship that seems too "churchy" (overly ritualized) and prefer what they describe as less formal "contemporary" or "praise" worship. Third, the vast majority report that their churches imagine no more specific vocation for them other than to "be a good Christian." 
Therefore, jumping into a community that practices communal morning and evening prayer, intentionally ritualized daily word and table worship, and revolves around deepened cultivation and further discernment of baptismal vocation would appear to be for them the religious equivalent of landing on the moon. Nor does the academy foreground what are assumed to be themes at the heart of the general adolescent context as the "problems" to be "posed" given teens' present situation. We do not start with school as societal warehousing, sex and sexualization, risk taking, ghettoization, silencing, status hierarchies, academic competition, sports, hormones, or MTV. Instead, we begin with an invitation to share in a patterned and practiced life through participation in the ordo. Almost none of our students, save a few overachieving Episcopaleans, would name this way of life as representing their concrete lived experiences. (I should note that our communities are almost exclusively Protestant.)

Indeed, not only does the academy appear not to "begin with the peoples' experience" in the Freirean sense, it engages in what many students already have concluded are the signs and practices of the oppressors. The academy prays "rote" prayers, practices "empty" rituals, builds entire faculty teaching plenaries around the "mere" symbol of water, speaks of the necessity of order in relation to freedom, of tradition in tension with innovation. Much of this strikes some students, at least initially, as a vast conspiracy. And admittedly, their suspicion is not unfounded. Throughout its history, the church often has employed its "holy things" -- book, bath, table and calendar -- to exclude persons from rather than to invite them into the Reign of God. ${ }^{2}$ Perhaps for this reason many Protestant students arrive pre-formed into a ritual symbolic (though often unwitting) iconoclasm. At any rate, not all students are immediately elated over the ordo's way of playing church.

While the academy's pedagogical practices seem not to qualify as adequately contextual in the strictest Freirean sense, they may yet be construed as faithful to the spirit of Freire. First, as noted above, the academy is indebted to Freire for the ability to see how past practices of youth ministry in North America were domesticated by other cultural agendas and practices. Youth ministry needed to change, and the youth academy proceeds self-consciously from that insight. Freire also helped youth ministry theorists recognize how domesticated youth ministry pedagogies were forming young adults with little or no sense of distinctive Christian vocation. Thus, the youth academy selfconsciously seeks to assist students in deeper cultivation/discernment of vocation. The question of how the ordo may qualify as authentic adolescent context, however, is more complex. My engagement with Freire on this point is wrought from an amalgam of theology, phenomenology, anthropology, and biology. The upshot is this claim:

\footnotetext{
${ }^{2}$ The question of the dynamics of power in relation to pedagogies of context is one that I am not able to consider at length in this essay. Freire, of course, locates his liberative pedagogical approach in a particular context (at the margins) with regard to power dynamics. Even though the ordo is unfamiliar to many students, its perceived marginality does not assume or create for them the same dynamics of difference or power as does, for example, poverty in relation to wealth. Indeed, given this reality, posing the ordo as contextual pedagogy may strike some as dressing the wolf in sheep's clothing. It strikes me, however, that much water has already gone down the river in this regard. Groome's approach is indebted to Freire but does not require persons to be located at the margins of power. And in works like Pedagogies for the NonPoor others wrestle honestly with questions of social location, the dynamics of power, and appropriating Freirean pedagogies.
} 
Ultimately, the ordo as pedagogical context is not alien, not a strange and foreign land to adolescents, but Home. This is true, in part, because adolescents, like all human beings are created bodily, relationally, and tuned to the rhythms of the wider creation. By offering abundant Bread and Water in a community patterned by work and Sabbath rest, the ordo provides Christian students the context for living the life they were created to live.

The paragraphs below are devoted to exploring in more detail the claim for the ordo's adequacy as a pedagogical context. In process I will attempt to show how fashioning pedagogies of context is a necessarily theological task for religious educators. In addition, I hope to show how the youth academy employs these pedagogies to distinctly theological ends.

\section{Theological/Epistemological Considerations for the Ordo as Contextual Pedagogy}

The first task is to offer a more detailed account of the "suitability" of the ordo to adolescent experience and to the task of their Christian religious education. This account is located at the intersection of Christian theology and the epistemological capacities of human being. Through their doctrines of creation and incarnation, Christians suggest that God is creator, that creation is good, and that, ultimately, God is revealed fully through Jesus' embrace of the very materiality of creation. Practicing the ordo unequivocally affirms these Christian theological claims for the goodness of creation and the reality of incarnation. It invites Christians to dispense with popular gnostic temptations to a spiritualized faith with no earthly implications and, instead, to immerse themselves in the practice of material things as essential graceful means for connecting with holy mystery and embodying faithful life. In other words, for Christians the distinctive character of God's self-revelation made manifest through the ordo is not that it makes an end run around their creatureliness but that it arrives smack dab in the middle of it. On purely theological grounds in relation to theologies of creation, incarnation, and the nature of revelation, therefore, the ordo is the "right" context for Christians -- including Christian youth -- who wish to live in relationship with God.

On the other side of the equation we examine the epistemological capacities of human being. Postmodern critique has exposed Enlightenment priviliging of "cognitive" knowing over other means of knowing including bodily, habitual, affective, imaginative, and intuitive. And as Elliot Eisner (1979) points out, cognition itself has lost its "scope and richness" in the process, reduced to meaning only "thinking with words or numbers by using logical procedures for their organization and manipulation and not thinking in its broadest sense" (98). In support of a post-modern re-turn to holistic knowing, neuroscientists (Damasio 1994; LeDoux 1996) provide evidence that so called "cognitive" brain activity is always interdependent with systems for affect that occur across the landscape of the entire body. Nevertheless, the outdated view of cognition reigns supreme in the world of adolescent schooling. This distortion of knowing may explain a number of dynamics for students at the youth academy. It suggests why, for example, the evocation of bodily, habitual, affective and imaginative knowing through ritual/symbolic action in the ordo may seem foreign to them at first. The narrow 
epistemological agenda of North American culture and schooling (which churches often have uncritically embraced) simply has not sought to cultivate these capacities in students. In contrast, the youth academy deems these alternative ways of knowing as vital for students' adequate perception of and full participation in God's graceful selfrevelation. This is true, first, because the content of this revelation cannot be exhausted by cognition, logic, or reason. Incarnation, for example, continues to resist the theologians' best efforts to rope and brand it with intellectual precision. The content of incarnation is a cognitive category buster. It goes deeper than discourse. That is why the church has also employed symbol, ritual, and metaphor to evoke something of this reality. These practices engage persons at a different level, one where they may feel more at home with the apparent logical contradiction of fully human/fully divine. Just as with content, so, too, the mode of God's self-revelation is never directed exclusively or even primarily to human cognitive capacities narrowly construed. Ritual symbolic action pregnant with metaphor and story engages persons bodily, affectively, intuitively, and imaginatively as well as cognitively. Thus the genius in the church's construction of the ordo is its invitation to persons to engage the entire range of their epistemological capacities in relation to holy mystery. Practicing the ordo invites students into the very center of who Christians claim God is and how God is revealed by cultivating in them ways of knowing essential to people of faith.

Related to this claim for reciprocity between God's self-revelation and human epistemological capacities is the academy's stated goal of forming students in coherent, embodied, and faithful ways of Christian life. Once again, alternative theological epistemological assumptions are critical to this goal. What the Christian tradition once knew (Paul, desert mothers and fathers, Edwards, Wesley, and more), post-modernism is helping Christians to remember: namely, that the heart matters for lived faith. It is impossible in this short essay to chronicle in detail the steps toward the theological and epistemological recovery of the importance of embodied affection. Instead I jump straight to conclusions. No longer is it helpful to assume that the self-conscious exercise of logical capacities for rational decision-making are the sole or even ultimate ingredient in virtue. Christians must finally learn to be moved wholly (affectively, bodily, imaginatively, habitually, as well as in self conscious and cognitively deliberate ways) by graceful mystery, if they are, in turn, to be formed in affections enabling them to respond to neighbors (including strangers) wholly with love. Thus, it is with straightforward intent that students are immersed in the ordo, a context where they may be moved toward God and neighbor. Such movement is possible, of course, because the ordo speaks the language of the heart.

An additional rationale for the ordo as context is its capacity to undergird theological critique and construction. As reflected in their pre-academy questionnaires, most students do not know the sweep of salvation history as witnessed to through book, bath, table and calendar, nor do they bring nuanced theological understanding with them. The youth academy proceeds, therefore, from the assumption that the ordo may provide a vital context for robust enactment of the stories of God's salvation and, by extension, that it may become a setting for theological genesis. For example, though (appropriately) no baptisms are performed at the youth academy, community members regularly see, hear, 
and touch the baptismal waters at daily corporate worship. Then, in the arts village and in their own worship planning (about which more below), students consider the evocative, multivalent, range of meanings for water (life, death, terror, peace and so on) and other Christian symbols. In addition, students, through preaching and study of the scriptures, learn to read the theologizing of Paul and others in light of these writers' imaginative reflections on actual baptismal practices in New Testament communities. Again, the academy does not assume this knowledge but judges essential the task of robustly enacting students into the breadth of stories and symbols from the Christian tradition.

\section{The Ordo as Context for Theological Reflection, Critique and Construction}

Buttressed by repeated student engagement in liturgical practices, cultivated aesthetic sensibilities, and hermeneutical skills, faculty are far better positioned to invite students into the important work of theological construction and critique. Below I attempt to spell out more concretely how the academy undertakes the work of critical-reflective and constructive theologizing with youth.

Consider Jesus' death. ${ }^{3}$ Nearly all academy students are familiar with (or regularly use) the phrase "Jesus died for my sins." Almost none of them, however, perceive that when reciting this "creed" they are giving voice to one of several possible theological accounts of atonement (Christian interpretations of Christ's saving work), in this case, Anselm's divine satisfaction theory. And no student (to date at least) has ever acknowledged considering previously how problematic this account may be for Christians. They have not noticed how Anselm's near exclusive focus on Jesus' death renders his earthly ministry and resurrection as insignificant. They have not perceived how Anselm's theory construes sin and redemption in individualistic terms. They have not considered how an account requiring the appeasement of an angry and violent God may be theologically and ethically problematic. In the academy community, however, students are invited to ritualize around a font imagined as both "tomb and womb." They learn by way of Romans 6 that they share in Christ's death and resurrection hope, and consider by way of II Corinthians 5 that the baptized are to share in Christ's ministry of reconciliation. Moreover, they practice reconciliation and hope through regular servant ministry in the Durham community. Grounded therefore in the ordo's full range of the enactment of Christ's death and life students acquire the practices, language, and sensibilities for critical constructive theological engagement with their inner Anselms. Specifically, when it comes time for a faculty-led plenary on Jesus' death, they have at their disposal a wider range of imaginative and practical resources to call upon in order to consider the possibility that in Jesus' death God was not vouchsafing violence but precisely nonviolence. And increasingly aware of the reality of baptismal vocation for faithful life in present and future, they are better positioned to comprehend the logic of a specific appeal from this faculty member to Christian peacemaking and non-violence located in that critical-constructive theological reinterpretation of Christ's death. Based on students' questions and comments, they find this account of Jesus' death deeply challenging, but, again, because of their practice of the ordo, no longer foreign to their experience.

\footnotetext{
${ }^{3}$ My reflections in this paragraph are sharpened by Leanne Van Dyk's response to the question: "How Does Jesus Make a Difference?" in Placher, ed. 2003, 205-220.
} 
Reported one student on this plenary session (led by Hauerwas): "I'd heard about him before I got here. I thought he was gonna' rock my world. But after everything else I've heard and done [at the academy], what he said made sense." This comment would seem to support the academy's hope and intent that the ordo provide students a context for formation, and, consistent with the aim of pedagogies of context, for critical transformation as well.

Notice how the academy's approach goes beyond teaching students to critically assess and deconstruct their contexts. While faculty in the youth academy teach skills for culture criticism and demonstrate how it informs theology, they also distinguish these skills from the work of theology. By doing so they avoid two potential pitfalls facing religious educators who embrace pedagogies of context. First, they resist teaching students merely to be critical. This is crucial for Christians seeking, ultimately, to be known by their love, and not by their cynicism. Second, keeping the focus on theology prevents critical methodologies from overwhelming or muting what may otherwise become the church's distinctive contribution to the world. In the end, it proceeds from the assumption that Christians, including Christian high school students, must find distinctly theological reasons for resisting war, and these require reflective theological practices of critique (including critique of Christian cultures and theological convictions) and construction.

\section{The Ordo as a Context for Revealing Difference}

As specified in the introduction, one purpose of contextual pedagogies is to assist learners in noticing the particularities of difference. I judged this task central to the Christian vocation for discerning truth and living truthfully. Having already argued that the ordo is not alien but Home for Christian youth as members of the human family, it may seem disingenuous to turn around and argue for its capacity to display difference as well. Yet given the theological breadth of the ordo this claim is not so far-fetched. The youth academy employs a manifold strategy to assist students in appreciating how the ordo may manifest difference and its significance for faithful Christian life. First, youth academy faculty teach explicitly on difference in light of the content of the ordo. With regard to the holy things of the ordo, they note how church's scriptures testify repeatedly to the significance of the "stranger" for revealing God. With the help of scripture they also invite imaginative interpretation of the communal meal as hosted by a stranger and open first to the least of God's people. Similarly, they point out how it is possible to see the washing away of pretense in the baptismal bath once rooted in sinful pride of place, class, ethnicity or gender while at the same time affirming the need for the diversity of baptized persons and gifts for the health of Christ's body. This straightforward teaching on the ordo's content invites heightened attention to the significance of difference. The content of the ordo is not primarily conceptual, however, it is embodied in daily practice. Much depends on whether the scriptures are opened wide or employed only selectively, on whether praise finds its counterpoint in lament, on who is allowed to preside over the community's meal, on who is welcomed to/excluded from the table, on whether the full range of the ritual symbolic gestures are explored, on the invitation to practice a variety of cultural interpretations and expressions of the ordo, on whether whooping can find a place along side of genuflecting, and so on. Students confront these realities directly 
when, in concert with adult mentors, they join together in small groups to plan and lead services of corporate worship for the community. Indeed, perhaps nowhere is the reality of difference more immediately manifested than in these planning sessions! Students and staff report that efforts to negotiate that difference faithfully and in light of their growing theological awareness number among their most taxing yet rewarding practices of the youth academy. Third, the liturgy planned must then be performed. Many students report that the visible presence of themselves and their peers in leadership roles in communal worship is itself acutely different from their experiences at home. Others note their sense of humility and empowerment when serving bread or cup to community members, including adult members. Year in and year out, these student-planned and led services manifest careful theological reflection, wide varieties of styles and cultural interpretations of worshiping practices, and, ultimately, wonderfully varied improvisation built on the ordo's fugal themes. A fourth strategy for attending to difference involves small reflection groups that meet daily. Repeatedly, students are asked what about their daily practice at the academy is different from more familiar points of reference and what this difference suggests to them about their own situatedness. Fifth, sessions in the academy "arts village" with theologically-trained artists-in-residence are conceived as contexts for students to cultivate alternative epistemological sensibilities. Through poetry, dance, pottery, music and more students are immersed in an aesthetic "language" of symbol, metaphor, and embodied practice. This aesthetic way of knowing is itself different, because, by nature it resists the flattening and positivistic tendencies of dominant epistemologies in the west. Walter Brueggemann (1982) calls this way of knowing a "prophetic enterprise." Further, he suggests, "persons nurtured into irony, metaphor and parable are persons who are likely to maintain some critical distance from every managed world" (53). Sixth, ordo-inspired practices of gleaning, sharing hospitality, and visiting the sick also manifest difference. Through these practices students meet agricultural workers, Christians of varying ethnicities and traditions, and persons who are sick or dying.

As noted above, in church practice the ordo has at times been made to mute or disparage difference. But the strategies described above related to the ordo are intended to promote the manifestation and critical awareness of difference consistent with the aims of pedagogies of context. Repeated encounters with and reflection upon ordo-manifested difference over two weeks time invite students to the notice realities of context. For many this is also an invitation to recognize their own privilege.

What evidence is there of transformation in the lives of students? Here circumspection and humility are required. The youth academy is still young, and no detailed answer to this question yet exists. I offer a few observations. Students consistently rank corporate worship highest ( 4.9 on a 5 point scale) out of all the academy practices. This suggests that initial suspicions in relation to the ordo do not persist. Upon returning home, many students (and pastors) report students' desire to "get where the action is" liturgically speaking. They seek out opportunities to serve and lead in corporate worship. They plan what they describe as more "substantive" worship for their youth groups. Students and pastors also report students' more frequent participation in eucharist where it is available and pointed critical questions about its lack of availability or what they judge to be its 
"lousy" enactment in some congregations. With regard to baptism, one student reported upon return home that she cried at the baptism of a child in her congregation "because for the first time, I was aware of what he was getting into." This would suggest that some students have continued to embrace the ordo as Home at home. Other students report taking up a variety of ministries from teaching inner city children liturgical dance, becoming confirmation sponsors, sponsoring Christian peace movements in their schools and churches, to assisting in HIV/AIDS communities. Students often cite a deeper appreciation for baptismal vocation and/or demonstrate awareness of specific dimensions of Christian stories or practices when interpreting these ministries. Another oft-cited example is the stated relation between deepened understanding of eucharist and taking up ministries related to hospitality and food distribution. For some students, awareness of baptismal vocation seems to persist even into the college years. In a recent e-mail, a college age alumna, after describing her major in middle eastern studies related to peacemaking and her conversations with third and fourth grade summer church campers on holy communion, closed with this comment: "[I] am definitely continuing to grapple with questions of faith in a distinct DYA way."

\section{Conclusion}

What, if any, "distinct DYA way" of doing theology the academy may offer is inseparably tied to the ordo but also to the conviction that the ordo functions in limited fashion as a useful pedagogy of context for theological genesis, critique and construction. In other words, the ordo seems capable of assisting in the formation and, perhaps, the transformation of faith in some high school students. The youth academy will never claim the ordo as the only context for faithful youth ministry. The academy experiment intends only to ask and answer whether the ordo may be one such context. In response we offer a hopeful (if still preliminary) "yes."

\section{References}

Brueggemann, W. 1982. The creative word: Canon as a model for biblical education. Philadelphia: Fortress Press.

Damasio, A. 1994. Descartes' Error: Emotion, reason and the human brain. New York: Putnam.

Edie, F. 2002. Cultivating baptismal spirituality in high school youth. Doxology 19:85107.

Eisner, E. 1979. The educational imagination: On the design and evaluation of school programs. New York: Macmillan.

Evans, A. 1987. Pedagogies for the non-poor. Maryknoll, NY.: Orbis Books.

Freire, P. 1994. The pedagogy of the oppressed. New York: Continuum Publishing Co.

Groome, T. 1991. Sharing faith: A comprehensive approach to religious education and pastoral ministry. San Francisco: Harper.

LeDoux, J. 1996. The emotional brain: The mysterious underpinnings of emotional life. New York: Simon \& Schuster.

Placher, W. ed. 2003. Essentials of christian theology. Louisville: Westminster John Knox Press. 
Warren, M. 1998. Youth, gospel, liberation. Dublin: Veritas. 